\title{
The Role of Religion, Philosophy of Life, Global Health, Traditional Medicine, and Past Experiences in the Covid-19 Pandemic Response: Zambia Case Study David Mutemwa, Veronika Zvánovcová, Anna Helová, Daniel D. Novotný
}

DOI: $10.32725 /$ cetv.2021.002

\begin{abstract}
:
Contrary to expectations, Zambia, similarly to many other Sub-Saharan African (SSA) countries and unlike most high-income Western countries, protected the public health against Covid-19 relatively successfully, at least during the first year of the pandemic. How is this possible given the resource-limited health care system, widespread comorbidities, and other adverse conditions in SSA? In this paper we discuss the possible role of religion, philosophy of life, global health approach, traditional medicine, as well as experiences with previous deadly epidemics, that might have contributed to Zambia's public health success. We draw on previous research concerning similar pandemic situations, as well as on current Zambian experiences, including those expressed in media and contained in accessible government records. We take Zambia's approach to be an inspiration for other societies so that it is not only the case that the more developed countries can contribute to the less developed ones, but indirectly also vice versa.
\end{abstract}

Keywords: Religion, Zambia, Covid-19, African philosophy, global health, traditional medicine

\section{Introduction $^{1}$}

Contrary to conjectures by global bodies, such as the World Health Organisation (WHO) and the World Economic Forum, ${ }^{2}$ most Sub-Saharan African countries (SSA), including Zambia,

1 We are grateful for discussions about the paper at various stages of its writing to Dagmara Dzúrová, Fr Clive Dillon-Malone, SJ, Světla Hanke Jarošová, Klára Hulíková, Lukáš Mareš, Fr. David Peroutka, OCD, and anonymous referees. We have received especially useful comments on the paper from one of the referees and Lukáš Mareš. Some results of the paper were presented at the joint seminar of AH and DN 'The Pandemic Raising Awareness of Global Health' presented at CEEPUS Virtual Summer School 'Learning Ethics Through the Pandemic: What can Covid teach us about the World, Human Society, and Ourselves?' organised by Dominik Opatrný at Palacký University Olomouc (18 $8^{\text {th }}$ March 2021).

2 'We should ... anticipate that in Africa a higher incidence of severe forms of Covid-19 will occur in younger patients because of the demographics and associated endemic conditions that affect the immune system. Malnutrition, anaemia, malaria, HIV/AIDS, and 
appear to have handled the recent Covid-19 epidemic with relative success so far. ${ }^{3}$ This observation surprises many high-income countries and is surrounded by speculations as to whether it is indeed the case what the reasons might be. ${ }^{4}$ In this paper we focus on several possible factors of this relatively successful response to the Covid-19 pandemic in Zambia. Our paper is divided into two main sections. First, we provide a brief profile of the country. Second, we outline the basics of the Covid-19 pandemic in Zambia and identify various factors that might have played a role in Zambia's relative success in dealing with it. We then focus on what we consider to be the five important and often overlooked socio-cultural factors: religion, philosophy of life, global health approach, traditional medicine, and community experiences with past epidemics and infectious diseases. (We also say that these factors contribute to the resilience of Zambians). ${ }^{5}$

What is the aim of our paper? This paper has been inspired by the perceptible efficacy (or as we say resilience) that Zambians and Africans in general have shown towards the Covid-19 pandemic, especially when compared to Western nations of Europe and North and South Americas. ${ }^{6}$ Since the experiences of more successful but poorer countries tend to be underrepresented in mainstream scholarly journals, we have decided to present our 'case for Zambia' and attempt to identify some of the reasons for Zambia's comparative success. We take our paper to be an interdisciplinary contribution that may fit into several disciplines. Most importantly to global/public health but also to inter-cultural philosophy, religious studies, anthropology, theology, development studies, community studies, etc. (all these inter-cultural comparative disciplines are themselves usually

tuberculosis are likely to increase the severity of Covid-19. Africa may not see the same narrative of "most people who get it will be fine" play out.' () Neema KASEJE, 'Why sub-Saharan Africa needs a unique response to the Covid-19', World Economic Forum (online), available at: https://www.weforum.org/agenda/2020/03/why-sub-saharan-africa-needs-a-unique-response-to-covid-19/, updated 30 ${ }^{\text {th }}$ March 2020, cited $14^{\text {th }}$ January 2021.

3 C Laundry SIGNÉ, 'Africa is more resilient than you think', Brookings (online), available at: https://www.brookings.edu/opinions/africais-more-resilient-than-you-think/, updated $25^{\text {th }}$ June, cited $14^{\text {th }}$ January 2021 . For comparative mortality statistics, see, for example, (C) WORLDOMETERS, Covid-19 Coronavirus Pandemic (online), available at: https://www.worldometers.info/coronavirus/, updated $20^{\text {th }}$ April 2021.

4 Cf. (C) Marek KERLES, 'Nebude lepší nechat Afriku promořit? ptají se vědci [Would it not be better to get Africa to reach natural herd immunity? the scientists ask]', Info.cz (online), available at: https://www.info.cz/zpravodajstvi/svet/nebude-lepsi-nechat-afrikupromorit, updated $14^{\text {th }}$ August, cited $14^{\text {th }}$ January. Cf. (C) Anne SOY, 'Coronavirus in Africa: Five reasons why Covid-19 has been less deadly than elsewhere', BBC (online), available at: https://www.bbc.com/news/world-africa-54418613, updated $8^{\text {th }}$ October, cited $14^{\text {th }}$ January. @ Kate HAIRISINE, 'Africa has so far been spared the coronavirus. Why? Made for minds', (online), available at: https://www. dw.com/en/africa-has-been-spared-so-far-from-coronavirus-why/a-52382666, cited $18^{\text {th }}$ January 2021.

5 Originally, the theory of resilience appeared in works of the Canadian ecological economist Crawford Holling (1930-2019). The word has acquired various meanings over the years and there seems to be no universally accepted definition of it in the literature, although at the core of various concepts there seems to be the idea of 'bouncing back from adversity (especially in an efficient way with respect to the available resources)'. One might object that the concept of resilience is not appropriately applied by us to Zambia's Covid-19 situation as it has suffered relatively little negative impact from the pandemic and so there is little to bounce back from. We take, however, resilience more broadly so that it includes not just actual but also potential adversity that a community foresees and by proactive measures prevents from becoming actual. We are aware that this may not be a common way to look at resilience and we do not insist on using the word 'resilience'. Readers may substitute it with a '(relatively) successful response' or some such concept. Additionally, in our paper, we relate (what we call) the resilience of Zambians to factors of religion, philosophy, global health, traditional medicine, and experience. This corresponds in part with the results of the researchers from King's College in London who have identified 'nine core elements of community resilience that were common among the definitions' as follows: 'local knowledge, community networks and relationships, communication, health, governance and leadership, resources, economic investment, preparedness, and mental outlook.' Cf. (c) Sonny S. PATEL, et al., "What Do We Mean by "Community Resilience"? A Systematic Literature Review of How It Is Defined in the Literature, PLoS Curr., $1^{\text {st }}$ February 2017, PMCID: PMC5693357 (online), available at: https://pubmed.ncbi.nlm.nih.gov/29188132/, cited $10^{\text {th }}$ April 2021. For an application of the original ecological concept of resilience to the Covid-19 epidemic, see $\odot$ Wenping XU, et al., 'The Influence of COVID-19 on Community Disaster Resilience', International Journal of Environmental Research and Public Health' 18(1):88. (online), available at: https://doi.org/10.3390/ijerph18010088, cited $20^{\text {th }}$ January.

6 Particularly surprising and tragic is the failure to respond effectively to Covid-19 in most rich Western countries. See, for example, Richard HORTON, The COVID-19 Catastrophe: What's Gone Wrong and How to Stop It Happening Again. Cambridge: Polity Press, 2020. For a thorough critical review analysing and defending Horton's main thesis of the Western Covid-19 failure (in Czech), see more (ODaniel NOVOTNÝ, 'Covid-19 katastrofa: Nad knihou Richarda Hortona', Filosofie dnes 12 (2) (online), available at: https:// filosofiednes.ff.uhk.cz/index.php/hen/issue/view/27, updated $7^{\text {th }}$ April 2021, cited $7^{\text {th }}$ April 2021, pp. 88-127. 
pursued in an interdisciplinary fashion and draw on methodologies commonly used in more basic, non-comparative disciplines). We do not aspire to identify all the factors of Zambia's success and we also do not discuss some of the well-established ones, such as the quick proactive prevention, strict hygiene measures and face masks, effective and trustworthy communication by public health authorities, etc. We are also aware of at least one other significant limitation of our paper, namely that we often draw not on resources specific to Zambia but applicable more generally. Hence our study is not a pure case study but a study in which we take up Zambia as an example whenever we are able to, tacitly drawing on rich direct personal experiences that three of the four authors of this paper have had with Zambian culture. As already mentioned, we focus on some of the less-known factors of Zambian pandemic response with the hope that more research will be carried out on them and the lessons learned will inspire other nations to improve the protection of human life and its dignity vis-à-vis the challenge of emergent infectious diseases.

\section{Background}

Zambia is a SSA country with an area of $752,618 \mathrm{~km}^{2}$ and a population of approximately 18 million, which means a relatively low population density of about 24 inhabitants $/ \mathrm{km}^{2}$. It is an inland state, bordering eight other countries, which makes it the region's transport hub, although the basic infrastructure remains underdeveloped. It has many national parks that have attracted tourists in recent years. ${ }^{7}$ It is divided into ten provinces. The Human Development Index ranks the country in the medium range and slowly rising. More than half of the population depends on agriculture, which is still the main source of income for women, who make up the majority of the rural population.

The region of today's Zambia was originally inhabited by Khoe-Sān (i.e., non-Bantu) peoples, belonging to the oldest evolutionary group of homo sapiens. In more recent times, coinciding with the European Middle Age, the Bantu-speaking population became prevalent. Europeans learned about Zambia especially thanks to the missionary, physician, and traveller David Livingstone (1813-1873), who came to the upper areas of the Zambezi River in $1855 .{ }^{8}$ The number of European settlers began to increase after the opening of mines in the north of the country, in the so-called Copperbelt. ${ }^{9}$ In 1899 and 1900 Barotziland-North-Western Rhodesia and North-Eastern Rhodesia, respectively, were formed as British protectorates, merging in 1911 into Northern Rhodesia, that was later to become Zambia. Northern Rhodesia was also federated at a time with Southern Rhodesia (now Zimbabwe) and Nyasaland (now Malawi) in the Federation of Rhodesia and Nyasaland. Over the years, Rhodesians increasingly objected to colonial rule. In 1962 the first democratic elections were held and on $24^{\text {th }}$ October 1964 the country became the independent Republic of Zambia, with Kenneth Kaunda (1924-2021) serving as the first President. ${ }^{10}$ Zambia's independence struggle and state-formation were grounded in Kaunda's Zambian Humanism, a socialism with theistic foundations, rooted in traditional Christian and African values

7 Cf. ( ) EMBASSY OF THE CZECH REPUBLIC IN LUSAKA, 'Summary Territorial Information of Zambia', (online), available at: http://publiccontent.sinpro.cz/PublicFiles/2020/05/04/Nahled\%20STI\%20(PDF)\%20Zambie\%20-\%20Souhrnna\%20teritorialni\%20 informace\%20-\%202020.094119592.pdf, updated 4th August 2020, cited 12 ${ }^{\text {th }}$ January 2021.

8 Cf. () George Albert SHEPPERSON, 'David Livingstone, Scottish explorer and missionary', Britannica (online), available at: https:// www.britannica.com/biography/David-Livingstone, cited $29^{\text {th }}$ January 2021.

9 Cf. @ Richard HAMILTON HOBSON, 'Zambia', Britannica (online), available at: https://www.britannica.com/place/Zambia, cited 29 January 2021.

10 Cf. Ondřej HULEC, Jiří OLŠA, Dějiny Zimbabwe, Zambie a Malawi, Praha: Lidové noviny, 2008, 342-344. Andrew ROBERTS, A History of Zambia, London: Heinemann Educational Publishers, 1977. 
such as altruism and community. ${ }^{11}$ (Similar ideas and ideologies were also introduced by other African independence politicians in Tanzania, Zaire, Ghana, etc.) Kaunda's socio-economic views failed, but many of his underlying ideas and principles, such as the human person at the centre, human dignity, non-exploitation, equal opportunity, hard work, working together, extended family, loyalty and patriotism are not specific to Kaunda's Zambian humanism and live on. ${ }^{12}$

During the early years of independence, Zambia was comparatively prosperous thanks to its copper mines. In 1972, a one-party government seized power in Zambia, a new constitution was introduced, and the president gained extraordinary powers. Under Kaunda's leadership, Zambia underwent a period of economic and political crisis until 1991 when his regime ended. ${ }^{13}$ The new political leadership of the second President Frederick Chiluba (1991 to 2002) sharply criticised the former president and promised a new and better era, which, however, did not come. ${ }^{14} \mathrm{~A}$ slow economic recovery only came with the third President Levy Mwanasa (2002 to 2008). Reforms and anti-corruption efforts continued also under the next four presidents (including a brief acting presidency of Guy Scott, a white Zambia-born economist of Scottish origin).

In 2011, Zambia reached the status of a middle-income country. ${ }^{15}$ However, in 2015, because of an interplay of high government spending, a budget deficit, a fall in world copper prices (the main trade item), reduced agricultural yields, and an energy crisis caused by water scarcity and rising inflation (GDP hit a 15-year low in 2015), the International Monetary Fund ranked Zambia among the economically most affected non-oil economies in SSA. Zambia ranks among the countries with the largest social disparities between rich and poor people in the world (high Gini index) and one of the highest levels of chronic poverty. Girls and women are particularly vulnerable and suffer from poverty and lack of education. ${ }^{16}$

According to UN estimates, Zambia has one of the fastest growing populations in the world, with the current population expected to triple by 2050. At the same time it is one of the countries with the lowest life expectancies in the world, which is due to the lack of affordable quality health care, including neonatal and paediatric care, resulting in high maternal and infant mortality rates. ${ }^{17}$ In 1991, the Zambian government launched health policy reforms characterised by a transition from a heavily centralised health care system. ${ }^{18}$ (The protection of public health in Zambia is set

11 For a brief but clear overview, cf. @ Clive M. DILLION-MALONE, S.J., Zambian Humanism, religion and social morality, Ndola, Zambia: Mission Press, 1989; () Ikechukwu Anthony KANU, O.S.A. 'Kenneth Kaunda and the Quest for an African Humanist Philosophy', International Journal of Scientific Research, Volume 3, Issue 8, Aug 2014, ISSN No 2277 - 8179. Kaunda himself authored several volumes about his views, such as Humanism in Zambia and a Guide to Its Implementation, first published in Lusaka in 1968.

12 () Raymond M. MWANGALA, 'Found a modern nation-state on Christian values? a theological assessment of Zambian humanism', Dissertation, University of Kwazulu Natal, 2009 (online), available at: https://researchspace.ukzn.ac.za/xmlui/handle/10413/503, cited $20^{\text {th }}$ January 2021. For a philosophical analysis of Kaunda's concept of Man-Centeredness, see () Hanry S. MEEBELO, 'The Concept of Man-Centredness in Zambian Humanism', The African Review, Vol 3 No 4, 1973 (online), available at: https://journals.co.za/doi/ pdf/10.10520/AJA00020117_213, cited 30 $0^{\text {th }}$ March, pp. 559-575.

13 (C) Andrew D. ROBERTS, 'Zambia', Britannica (online), available at: https://www.britannica.com/place/Zambia/Zambia-in-the-21stcentury.html, cited $29^{\text {th }}$ January 2021.

14 Cf. Ondřej HULEC and Jiř́ OLŠA, Dějiny ..., p. 379.

15 () THE WORLD BANK IN ZAMBIA, 'Zambia', (online), available at: https://www.worldbank.org/en/country/zambia/overview, cited $22^{\text {nd }}$ January 2021. In terms of Hans Rosling's four levels of income, Zambia is currently on level 2, receiving between $\$ 2$ and $\$ 8$ a day. This is the level above extreme poverty and characterises the largest group of people around the world who typically may buy food that they did not produce, sleep on a mattress, own a gas canister for cooking and travel by bicycle or motorbike. Available at: Hans ROSLING, Ola ROSLING and Anna ROSLING RÖNNLUND, Factfulness: Ten Reasons We're Wrong About the World - and Why Things Are Better Than You Think. New York: Flatiron Books, 2018, pp. 32-39.

16 Cf. ( ) MINISTRY OF FOREIGN AFFAIRS OF THE CZECH REPUBLIC, 'Cooperation of the Czech Republic of Zambia 2018-2023', (online), available at: http://www.czechaid.cz/wp-content/uploads/2018/12/3173256_2067112_program_Zambie_CRA_2018.pdf, cited $13^{\text {th }}$ January 2021, p. 6.

17 Ibid.

18 Cf. ( ) CENTRAL STATISTICAL OFFICE (CSO), MINISTRY OF HEALTH (MOH), TROPICAL DISEASES RESEARCH CENTER (TDRC), UNIVERSITY OF ZAMBIA, MACRO INTERNATIONAL INC., Zambia 'Demographic Health Survey 2013-2014', (online), 
out in Act No. 295/1995 Coll. - on the prevention and reduction of diseases and on the general regulation of all matters relating to the protection of public health in Zambia.)

Zambia is a multi-ethnic state with over seventy ethnic groups. The Zambian population is made up of $99.5 \%$ of indigenous African tribal groups, the most significant of which are: Bemba $21 \%$, Tonga $13.6 \%$, Chewa $7.4 \%$, and many others. Economically important groups are Indians, Lebanese, Zimbabweans, and South Africans. Zambia is deeply religious with 92\% professing Christianity (mostly Protestants, but with significant Catholic and African Christian confessions). There are also religious minorities (Muslims 3\%, Buddhists and Hindus 3\%, and local religion 2\%). ${ }^{19}$

\section{Covid-19 in Zambia}

Zambia reported its first cases of Covid-19 on $18^{\text {th }}$ March $2020 .{ }^{20}$ As of $21^{\text {st }}$ January 2021 , there had been over 42,213 confirmed cases, 597 deaths (1.4\% case fatality rate), with nearly $75 \%$ recovery rate to date. Confirmed cases were most prevalent in three provinces: Lusaka, Copperbelt, and Central. Throughout most of the period of the epidemic, Zambia maintained a relatively low caseload with less than 2,000 cases per month. The country experienced a surge in cases in the period of June - September 2020 (up to 6,200 cases per month) and was on the above date currently facing a second wave of cases that started in December 2020. According to the dashboard of the Zambian Ministry of Health, the monthly rate increased in January to about 23,000 cases; the effect of this second wave remains to be seen. ${ }^{21}$

Still, Zambia's cumulative mortality, that is, the number of deaths per million, remains rather low: 41 as of January 2021, which is 33 times lower than in the U.S. and 47 times lower than in Czechia. Even when we adjust for probable Covid-19 death underreporting and lower testing rate we may still consider the handling of the epidemic to have been a success so far and acknowledge the remarkable resilience of the Zambian population and the efficiency of public health system. Even when one adjusts for the relatively low-rate of testing, underreported Covid-19 deaths, ${ }^{22}$ and demographically one of the world's youngest population structures, Covid-19 mortality and infection rates are dramatically lower in Zambia than they are in most very high-income countries: as of mid-April 2021, the cumulative registered mortality is around 40 times lower than in Czechia and 25 times lower than in the U.S.). ${ }^{23}$ This is despite the resource-limited health care system and widespread comorbidities.

available at: https://www.dhsprogram.com/pubs/pdf/fr304/fr304.pdf, cited $20^{\text {th }}$ January 2021, p. 28.

19 (C) THEODORA, 'Zambia People 2020', Theodora (online) available at: https://theodora.com/wfbcurrent/zambia/zambia_people.html., cited $29^{\text {th }}$ January 2021.

20 Cf. @ UNITED NATIONS COVID-19 EMERGENCY APPEAL ZAMBIA, 'Overview of the Crisis', (online), available at: https://reliefweb. int/sites/reliefweb.int/files/resources/ZAMBIA_\%20COVID-19_Emergency_Appeal.pdf., updated May 2020, cited 20 $0^{\text {th }} J a n u a r y ~ 2021$, p. 6.

21 Cf. ( ) WIKIPEDIA, 'COVID-19 pandemic in Zambia', (online), available at: https://en.wikipedia.org/wiki/COVID-19_pandemic_in_ Zambia.html, cited $30^{\text {th }}$ January 2021.

22 One needs to acknowledge that due to testing resources there is probably a more significant underreporting in Zambia than in Western countries. This is indicated also by some studies for Zambia and other SSA countries, such as Kenya. This, however, still does not explain the order of magnitude in the impact of Covid-19 when it comes to, for example, mortality and other relevant health and economic determinants. Cf. () Sophie YUOGA et al., 'Seroprevalence of anti-SARS-CoV-2 IgG antibodies in Kenyan blood donors', Science (online), available at: https://science.sciencemag.org/content/371/6524/79, updated $1^{\text {st }}$ November 2020, cited $14^{\text {th }}$ January 2021. On post-mortem surveillance in Lusaka, cf. ( ) Mwananyanda LAWRENCE et al. 'COVID-19 deaths detected in a systematic postmortem surveillance study in Africa', Thea medRxiv, (online), available at: https://doi.org/10.1101/2020.12.22.20248327, updated 24 ${ }^{\text {th }}$ December 2020, cited $24^{\text {th }}$ January 2021. For problems concerning the lack of precise mortality data in Africa, see further: (C) BBC NEWS, 'Measuring Africa's Data Gap: The cost of not counting the dead', (online), available at: https://www.bbc.com/news/worldafrica-55674139, updated $28^{\text {th }}$ February 2020, cited $12^{\text {th }}$ February 2021.

23 () WORLDOMETERS, 'Covid-19.... See also ( ) WHO AFRICA 'Dashboard, information, situational reports', (online), available at: https://www.afro.who.int/health-topics/coronavirus-covid-19, cited $1^{\text {st }}$ February 2021. 
How can the comparative success of Zambia and a few other SSA countries in dealing with the pandemic be explained? Each nation and community has its own unique set of characteristics applied to internal structures, local history, and traditions, with social, cultural, philosophical, legal, and economic backgrounds, political manifestations, as well as religiosity. These factors influence a community's outlook and perception. ${ }^{24}$ Various factors explaining or at least contributing to the resilience of countries such as Zambia have been suggested:

- Biological: Africans are biologically more resistant to infection, e.g., genetically. ${ }^{25}$

- Geographical: Some conditions, such as higher average temperatures, may promote lower rates of infections. Sunlight, which results in the formation of vitamin D, is known to boost immunity. There is lower population density in most parts of SSA where people live in communities that are tens of kilometres apart in most of the land.

- Political: Although the central government is widely distrusted by the population and corruption has been notoriously widespread, ${ }^{26}$ there are many well-respected local leaders who took on a proactive stance early, as soon as they learned about the deadly virus. ${ }^{27}$ Also, it needs to be acknowledged that the central government reacted rather quickly and efficiently in at least some respects, for example, by implementing nation-wide measures even before the first case was detected in the country. ${ }^{28}$

- Religious: Zambians are deeply religious with a great respect for various religious authorities and the views of local religious authorities seem to have helped to respond to the pandemic effectively. Unlike in countries such as the U.S. and Brazil, masks, physical distancing, handwashing, and other effective non-pharmacological interventions were promoted by leaders across the religious spectrum.

- Philosophical: there are several aspects that seem to contribute to the pandemic resilience, such as the traditional African emphasis on communality, solidarity, and respect for the elderly. (Additionally, the Zambian humanism of the first president-philosopher Kaunda, despite a rather failed economic theory as part of it and its current unpopularity, may have had an indirectly beneficial effect, too. $)^{29}$

24 Brankica MILOJEVIC, 'Influential factors in the urban transformation of cities in Bosnia and Herzegovina during the transition period', ISOCARP (online), available at: http://www.isocarp.net/Data/case_studies/2146.pdf, cited $20^{\text {th }}$ January 2021, p. 1.

25 This seems to be a popular but unfounded hypothesis, although there are differences in immune responses across races. Cf. ( ) Hélène QUACH et al., 'Genetic Adaptation and Neandertal Admixture Shaped the Immune System of Human Populations', (online), available at: https://pubmed.ncbi.nlm.nih.gov/27768888/, cited $17^{\text {th }}$ January 2021, 643-656. However, so far the influence seems to be going the other way around, that is, Africans appear to be more vulnerable, although how significant the biological contribution is remains to be seen. Cf. (c) Christine RO, 'Why some racial groups are more vulnerable', BBC (online), available at: https://www.bbc.com/future/ article/20200420-coronavirus-why-some-racial-groups-are-more-vulnerable, cited $21^{\text {st }}$ January 2021.

26 'Corruption remains a major problem in Zambia despite the existence of a number of anti-corruption watchdogs and rigorous changes in the law to curb the vice. The public sector remains the most severely affected. Reviewing corruption trends in Zambia from 1964 to 2017 shows that corruption has increased since the transition into multiparty democracy and the subsequent economic liberalization of 1991. ... corruption had found its resting place in Zambia spreading its ugly fangs across all sectors of the economy because of lack of political will to fight the vice, lack of transparency and accountability, poor enforcement of the law and a rampant culture of political patronage.' (c) Bahadur SAPKOTA and Martin MUSAMBA, 'Understanding corruption in Zambia: an analysis of the challenges in eradicating the scourge', (online), available at: https://www.researchgate.net/publication/322222474, cited $29^{\text {th }}$ January 2021.

27 As far as we can say from interaction with local people, most Zambians have lost trust in the central government to the extent of relying mainly on local authorities and local media, such as local radio stations and social media for credible information. All major private media houses have been closed by the government, including the leading private newspaper (The Post), and the two-leading privateowned television stations (Movie TV and Prime Television). State media are controlled and politically censured.

28 In particular, on $13^{\text {th }}$ March 2020, the government promulgated an urgent appeal in accordance with The Public Health Act, Laws Volume 17, CAP 295 of Zambia and Covid-19 related statutory instruments Nos. 21, 22 and 62 of 2020, () GOVERNMENT OF ZAMBIA, 'Statutory instruments No.21, 22 and 62 of 2020', (online), available at: https://zambialii.org/zm/blog/Statutory\%20Instrument\%20 No.22\%20of\%202020\%20\%282\%29.pdf, updated $13^{\text {th }}$ March 2020, cited $20^{\text {th }}$ January 2021.

29 Traditional respect for the elderly implies care for them as a condition and source of a fulfilled life. See, for example, Barney COHEN and 
- Global health related: Zambia adopts an approach to health care that is informed by results from global health discipline that encourages, for example, task shifting, community involvement, and other effective means in public health protection. There has also been emphasis on suppression and minimising the number of infections rather than mere mitigation of and reliance on rather poor capacities of hospitals. ${ }^{30}$

- Medical: There is a tradition of local medicine complementary to standard 'Western' medicine. Some of these practices and beliefs may have been beneficial in the mitigation of the epidemic.

- Historical: One of the factors contributing to the so far low number of Covid-19 infected persons and deaths in Africa is probably the countries' experience of previous and current epidemics, so the population is well disposed toward collaboration with public health officials.

Biological, geographical, and political factors do not seem to have contributed substantially to the Zambian resilience to the Covid-19 epidemic: there is little evidence for greater biological resistance of Zambians to Covid-19. Additionally, weak population health, high mortality, comorbidities, and a resource-limited health care system work against the effective pandemic effort. Geography as a factor in pandemic resilience is also weak as one may easily object that Zambia has many so-called compounds (slums) which are very crowded. Large families live, for example, on five square meters. ${ }^{31}$ Mobility within and across communities may be lower than, for example, in Western countries but it is still rather intensive. As for political factors, we have already noted that central authorities reacted early to the news of the pandemics and effective measures such as masks, physical distancing, and hand washing were implemented, also with the help of trusted local authorities. (The central authority encouraged this and did not play a negative role as it did in some other countries, where the central governments sometimes undermined a more proactive grassroots approach to the pandemic by downplaying the risks and benefits of effective non-pharmacological interventions fearing adverse short-term effects on economy.)

We take the remaining five factors, that is, (a) religion, (b) philosophy of life, (c) global health (d) medical beliefs, and (e) past experiences to be more significant than the rest; at any rate we will focus on them in what follows.

\section{(a) Religion}

Religion is a fundamental influence in the lives of most Africans, including Zambians, even perhaps the most important one. ${ }^{32}$ Religion affects every aspect of the life of the African people. Since it is rather well established in the literature that religion significantly contributes to or at least correlates with resilience during adverse circumstances such as natural disasters, war, or personal tragedy, we consider this to be the case also in Zambia's Covid-19 response. ${ }^{33}$ Religiosity can be

Jane MENKEN, eds. Aging in Sub-Saharan Africa: Recommendation for Furthering Research, Washington, DC: National Academies Press (US), 2006. Furthermore, the elderly provide wise counsel in African communities about risky situations, such as Covid-19. Related to this well-known advisory role of the elderly is the existence of philosophical sages in African traditions, as argued by the Kenyan philosopher Henry Odera ORUKA (1944-1995), see his Indigenous Thinkers and Modern Debate on African Philosophy, Leiden: E. J. Brill, 1990.

30 Some authors argue that the strategic decision to suppress/eliminate versus to merely mitigate ('flatten the curve') the infection is the most important factor in how countries manage Covid-19. () Daniel NOVOTNÝ, 'Covid-19 katastrofa..., pp. 88-127.

31 Cf. (c) ČESKÁ TELEVIZE, Kibera: 'The Story of the Slum', (online), available at: https://www.ceskatelevize.cz/porady/11565644099kibera-pribeh-slumu/21756227052/, cited $15^{\text {th }}$ January 2021.

32 ( ). O. AWOLALU, 'What is African Traditional Religion? Comparative religion study', 10(2):1. World Wisdom (online), available at: www.studiesincomparativereligion.com, cited $20^{\text {th }}$ January 2021.

33 (c) Steven PERUTINSKIJ, Aron D. CHERNIAK and D.H. Rosemary, 'COVID-19, Mental Health and Religious Coping among American Orthodox Jews', J Relig Health 59, pp. 2288-2301 (2020) (online), available at: https://doi.org/10.1007/s10943-020-01070-z, cited 23 ${ }^{\text {rd }}$ January 2021; @ Edward B. DAVIS and Cynthia N. KIMBALL et al., 'Faith as a result of disaster: A longitudinal qualitative study 
a powerful resource for mental health as it involves a framework of meaning-making, which is associated with reduced psychological stress and a value-based pursuit of psychological well-being. Religion provides a source of attitudes and cognitions that can reframe negative events into less stressful frames. When applied in the context of life stressors, religion can be also a positive coping mechanism involving the use of religious beliefs and behaviours to facilitate problem-solving or to alleviate the negative emotional consequences of stressful circumstances. ${ }^{34}$ Zambians during the pandemic and people in general often turn to religion when coping with stressful phenomena and they do so mostly with positive outcomes. ${ }^{35}$

As with most value systems and systems of ideas, religion addresses among other things issues of human well-being, good life and good society, and transformation of the world. As such, an African perception of human well-being as well as health risks, such as the Covid-19 pandemic, can also be framed in a religious story that appeals to beliefs and values in a conceptual response and required control measures. ${ }^{36}$ Religion in Zambia and Africa in general is intrinsically linked to how people perceive life, including health and disease, such as the Covid-19 pandemic. People's religious beliefs affect their perception of the living situation and provide resources for their adherents, which can be mobilised by required behavioural reactions and corrective interventions. The Dutch scholar of religion and development Gerrie Ter Haar and the British historian Stephen Ellis identify four sources in which religion is integral to Africa's development. ${ }^{37}$ (As a worthwhile project one could apply these in more detail to analyse Zambia's Covid-19 response in light of its religiosity; here we make only a few preliminary suggestions on how it could be done.)

- Religious ideas, or people's beliefs, contribute to the formation of values and assumptions that people consider, individually and collectively as a society. Matthew Clarke (2011), an Australian scholar of development studies, also argues here that the religious ideas affect the moral base of the society, which in turn affects people's perceptions and their response to the circumstances of human well-being, poverty, or deprivation. ${ }^{38}$ Zambian Christians, for example, believe that Christianity informs the way our society is and should be organised and the way we live, including things pertaining to our health, customs, laws, economy, politics, art, ca-

of religious attachment after a catastrophic flood, Psychological trauma: theory, research, practice and politics', $11^{\text {th }}$ September 2019 (online), available at: https://pubmed.ncbi.nlm.nih.gov/30589318/, cited 10 ${ }^{\text {th }}$ April 2021, pp. 578-587; @ Joseph HENRICH et al., 'War increases religiosity', Nature Human Behaviour 3, 2019 (online), available at: https://www.nature.com/articles/s41562-018-0512-3 3(2), cited $10^{\text {th }}$ April 2021, pp. 129-135.

34 ( ) Gene G. ANO and E. B. VASCONSELES, 'Religious coping and psychological adjustment of stress: meta-analysis', Journal of Clinical Psychology, 61(4), (online), available at: https://pubmed.ncbi.nlm.nih.gov/15503316/, cited $21^{\text {st }}$ January 2021, pp. 461-480; ( ) W. R. SMITH and J. D. ATEN et al., 'The psychological study of religion and spirituality in a disaster context: A systematic review', (online), $11^{\text {th }}$ September 2019 (6), DOI: 10.1037/tra0000431 (online) available at: https://doi.org/10.1037/tra0000431, cited 22 $2^{\text {nd }}$ January 2021, pp. 597-613.

35 One of the reviewers has pointed out that the point we make in this section is not quite coherent as Covid-19 pandemic in Zambia does not have manifestations either of 'disaster' or 'trauma' and anyway what we say is rather applicable to Western way of religious coping. As to the first part of the objection we take a pandemic to be a challenging situation in any society, even those that have successfully suppressed the spread of the infection. (These societies need, for instance, at least to remain vigilant for a possible re-introduction of the infection from areas and countries that have not been able yet to get the virus under control). So, the current pandemics negatively affected most if not all societies worldwide, and at any rate also Zambia. In all societies people need to cope with some negative impact. We acknowledge, however, that the second part of the objection is quite valid: cross-cultural empirical study would need to be carried out to determine how much one can apply results from one culture to another in the current context; our suggestions here are quite tentative.

36 ( ) Hannah Lindiwe DE WET, 'Understanding transformational developments in the World Vision of South Africa: conceptualization and commissioning', 2011 (online), available at: https://www.semanticscholar.org/paper/Understanding-transformational-development-inworld-Wet/bleaf84eef6798379b12f452fb52e5f0f607089c, cited $20^{\text {th }}$ January 2021, pp. 7-8.

37 (C) Gerrie Ter HAAR and Stephen ELLIS, 'The role of religion in development: towards a new relationship between the European Union and Africa', Eur J Dev Res., 18 (3), 2006 (online) available at: https://doi.org/10.1080/09578810600893403, cited 23 ${ }^{\text {rd }}$ January 2021, pp. 351-367.

38 Mathew CLARKE, Development and religion: theology and practice, Cheltenham: Edward Elgar publishing LTD, 2011. 
lendar, holidays, and other moral and cultural priorities. ${ }^{39}$ Therefore, the perception of health and well-being, as well as the means to achieve it in an African context, cannot be formulated exclusively materially, but should also draw on religious sources. ${ }^{40}$

- Religious practices, including ritual behaviour, in Africa can make a significant contribution to how people perceive health risks. Practices such as social activity or caring for the poor during a health pandemic, such as the current Covid-19 pandemic, have direct religious roots and consequences. Church services, including sermons and prayers for the sick, can also be mobilised in the service of corrective goals, as is the case in the 'Channels of Hope World Vision HIV/AIDS' stigma interventions that operate through Church services. ${ }^{41}$

- Religious organisations, such as church denominations and other faith-based organisations, can be mobilised for preventive and corrective intervention. As such, they act as important agents, partners, and vehicles in the process of fighting the pandemic. In Zambia, for example, the UN Emergency Call for Zambia ${ }^{42}$ accepts faith-based organisations, such as Expanded Church Response, as important agents and partners in the fight against the Covid-19 pandemic. In several other repeated cases, the Zambian government has called on the churches to work corporately with the government's line of ministries in sensitising the nation's general population in light of the Covid-19 global pandemic and the control measures needed to reduce it.

- Religious or spiritual experiences, such as the subjective experience of internal change or transformation, serve as sources of inner strength and a path to empowerment. ${ }^{43}$ In this case, inner strength is a necessary dimension and precursor to the individual's perception of life, because access to spiritual empowerment creates an incentive for actions that can change the material world of man or community. Looking from this perspective, it is quite vivid why most African religious beliefs, such as Pentecostal and charismatic Christians, also believe in divine healing and protection, an aspect that casts a somewhat less threatening picture of disease and pandemic for most of those who adhere to such a belief system. ${ }^{44}$

\section{(b) Philosophy of Life}

Since the seminal work La Philosophie Bantoue by Placide Tempels (1906-1977), a Belgian Franciscan missionary in Congo, published in 1945, it has been acknowledged that not just religion but philosophy plays a significant role in the lives of SSA populations. ${ }^{45}$ The nature of SSA philosophical elements and practices is subject to debate, for example, with respect to questions such

39 This is a significant phenomenon not just in and for Zambia, cf., for example, the U.S. based historian, drawing on his earlier book publications @ Phillip JENKINS, 'The Future of World Christianity Is African', (online), available at: https://www.thegospelcoalition.org/ article/future-christianity-african/, updated August 2020, cited $19^{\text {th }}$ April 2021.

40 Gerrie Ter HAAR, Religion and development: ways of transforming the world, London: Hurst and co., 2011, p. 11.

41 (C) Hannah Lindiwe DE WET, 'Understanding', p. 9.

42 (c) UNITED NATIONS COVID-19 EMERGENCY APPEAL ZAMBIA, 'Overview of the Crisis', (online), available at: https://reliefweb. int/sites/reliefweb.int/files/resources/ZAMBIA_\%20COVID-19_Emergency_Appeal.pdf., updated May 2020, cited 20 ${ }^{\text {th }}$ January 2021, pp. 26-27.

43 () Gerrie Ter HAAR and Stephen ELLIS, 'The role of religion', p. 356. The authors have also developed a useful framework for thinking of religion and politics in Africa, which is relevant for what we say in the next section about church-state relations in Zambia: ( ) Gerrie Ter HAAR \& Stephen ELLIS. 'Religion and Politics: Taking African Epistemologies Seriously', Journal of Modern African Studies 2007, Vol. 45, No. 3, (online), available at: https://doi.org/10.1017/S0022278X07002674, cited 23 $3^{\text {rd }}$ January 2021, pp. 385-401.

44 (C) Colins AIRHIHENBUWA, 'AIDS perspectives in Africa: strategies for prevention and control', Aids Education and Prevention (online), available at: https://pubmed.ncbi.nlm.nih.gov/?term=Airhihenbuwa+CO\&cauthor_id=2641219, cited 20 January 2021, pp. 57-69.

45 (C) The Revd. Father PLACIDE TEMPELS, 'La Philosophie Bantoue', Placide Tempels, translated in 1953 (online), available at: http:// www.aequatoria.be/tempels/FTEnglishTranslation.htm, cited $20^{\text {th }}$ January 2021. 
as whether they are implicit (ethnophilosophical, folk philosophy) or explicit (oral or literary sage philosophy). However, all these are called 'philosophy of life', a term used to refer to the cultural dispositions of communities and individuals toward the meaning of life and toward the fundamental values related to it, especially, in our context, health and disease, regardless of whether implicit or explicit. Although philosophies overlap with religions, the two should be distinguished, for example, by emphasis on reasoned discourse and only an external relation to the authority of divine persons, traditions, or revelations. ${ }^{46}$

In Zambia, the fusion between religion (Christianity and indigenous traditions), philosophy (Zambian humanism and other local traditions), and politics (Kaunda's socialism and Christian nation) is particularly strong. Since 1991 Zambia has been a self-proclaimed 'Christian Nation'. President Chiluba was supported by various Christian churches during the campaign of 1991, through which he became the second president of the republic. ${ }^{47}$ This study has established that President Chiluba felt obliged to pay to the Christian churches back for their support by declaring Zambia a Christian nation and appointing some pastors to serve in his government. Furthermore, President Chiluba was a 'born-again' Christian who felt that the peaceful transition from the second Republic to the third Republic was due to divine intervention. Therefore, to show appreciation to God and the Christian community, Zambia was to be declared a Christian nation. ${ }^{48}$ The president also publicly donated money to Christian churches, which caused a major rift in church-state relations as those who supported the declaration saw themselves as allies of the political administration and of 'true Christians'. On the other hand, those who opposed the declaration were perceived by 'born-again' Christians as leaders opposing the President, who was the anointed one of God. While it is often difficult to draw practical distinctions between religion, philosophy, and politics in the Zambian context, we may do so at least conceptually.

Central to the Zambian philosophy of life is solidarity, which is viewed as one of the fundamental values. ${ }^{49}$ A sense of national unity is also very much alive in Zambia, as expressed in the motto 'One Zambia - One Nation'. Despite various shortcomings, both the population and the government draw on these values in their commitment to public health. In this, a connection can be perceived between Kaunda's humanism, thought to be long gone and failed as it did not promote self-reliance and capitalistic innovativeness, and current popular philosophy or philosophy of life, as we call it here.

These philosophical attitudes implicit in Zambian and other African cultures are also described by researchers dealing with public/global health. For instance, Airhihenbuwa and Iwelunmor argue for the importance of culture in Africa's public health as it determines how individuals

46 Some of what we call 'philosophy' here would be relegated by many philosophers to anthropology departments. We adopt a more inclusive understanding of philosophy, similar to the project of 'anthropology of philosophy' of Kai KRESSE, Philosophising in Mombasa: Knowledge, Islam and Intellectual Practice on the Swahili Coast, Edinburgh: Edinburgh University Press, 2007. In general, we would like to see more philosophical and anthropological methodologies and traditions applied in global health research.

47 Moses ZWANYIKA, An ethical assessment of the relationship between the mainline churches and the state in Zambia, Dissertation - MA, Lusaka: The University of Zambia, 2013, p. 61.

48 President Chiluba also established what was called a 'Religious Affairs Desk' at the State House, which had the purpose of looking into the religious affairs of the nation and advise the presidency accordingly. The following three presidents, however, downplayed Chiluba's idea in this regard. During the regime of the current President Edgar Chagwa Lungu, the idea has not only been revisited but also expanded to the establishment of the new 'Ministry of Religious Affairs and National Guidance'.

49 This cultural emphasis on community is captured by the term 'ubuntu', meaning 'humanity', interpreted as 'I Am because We Are. This philosophical vision is developed especially in South Africa, see Mabogo P. MOORE 'Philosophy in South Africa Under and After Apartheid', in: A Companion to African Philosophy, edited by Kwasi WIREDU, Malden, MASS: Blackwell publishing, pp. 149-160. See also (C) Peter ADAMSON, 'I am because we are: Communalism in African ethics and politics', History of Philosophy without any Gaps (online), available at: https://historyofphilosophy.net/communalism, cited $1^{\text {st }}$ February 2021. 
and communities interpret diseases. ${ }^{50}$ In other words, culture is a building block for contriving a personal understanding of health and disease, whether in relation to the perceptions people may have about their health, or in describing their health-seeking practices. It would be therefore useful to decipher the impact of the African cultures on the perception of the Covid-19 pandemic so that more effective control measures capable of reducing the impact of the pandemic could be found. ${ }^{51}$ According to De Wet, ${ }^{52}$ cultural values and norms are the most touted perceptions of physical well-being and also appeal to spiritual power and influence. Airhihenbuwa and Iwelunmor point out that 'culture is a collective sense of consciousness with both quantifiable and incalculable components. ${ }^{53}$ In 1989 Airhihenbuwa developed a useful framework for thinking about cultural, that is, also philosophical and religious, components relevant for public health and health education programmes in Africa, called PEN-3. This framework makes use of three primary domains: cultural identity, relationships and expectations, and cultural empowerment. Each domain consists of three factors that make up the acronym 'PEN': person, extended family, neighbourhood (the domain of Cultural identity); positive, existential, negative (the domain of Cultural empowerment); and perceptions, enablers, nurturers (the domain of Relationships and expectations). The PEN-3 framework emphasises behaviour in the broader context of culture to recognise roles, values, and norms, that is, the ethical, epistemic, and ontic aspects of a culture, which are conducive or not to different types of activities aimed at promoting health and well-being. It offers a way to deal with the philosophical and cultural dimension for solving health problems.

\section{(c) Global Health Approach}

The Zambian approach to the protection of public health has been informed by global health initiatives. ${ }^{54}$ This means, among other things, that the Zambian public health system is well integrated with various well-established and effective home-based and community involvement methods such as the task shifting of simple health care to trained community workers. ${ }^{55}$ During the Covid-19 pandemic, this system has been utilised to a larger extent, allowing health care facilities to focus only on the most serious cases. ${ }^{56}$ Hence, in spite of the severely limited capacity of health care services in the country, the Zambia Covid-19 emergence response and health systems preparedness project revealed reasonable strengths in Zambia's public health preparedness and response capacity. ${ }^{57}$

50 (C) Colins AIRHIHENBUWA, Juliet IWELUMNOR, Why culture is important in reducing the burden of NCDs and CDs in Africa, Commonwealth Health Partnership 2012, Social and cultural determinants (online), available at: http://www.chpa.co/Documents/ WhyCultureConnects-DrAirhuhenbuwa.pdf, cited $20^{\text {th }}$ January 2021. For philosophical aspects related to public health and identity, see Colins AIRHIHENBUWA, Healing Our Differences The Crisis of Global Health and the Politics of Identity. Plymouth: Rowman \& Littlefield Publishers, 2007.

51 It would also be a worthwhile project to make an empirical probe into the specific pathways by which tribes and people groups in Africa adapt and show resilience to pandemics like Covid-19 and other infectious diseases.

52 (c) Hannah Lindiwe DE WET, Understanding ..., p. 28.

53 (c) Colins AIRHIHENBUWA and Juliet IWELUMNOR, Why culture is important in..., p. 108.

54 () GLOBAL HEALTH ZAMBIA, 'CDC Impact in Zambia' (online), available at: https://www.cdc.gov/globalhealth/countries/zambia/ default.htm, cited $10^{\text {th }}$ April 2021; () GLOBAL HEALTH CORPS, 'Zambia', (online), available at: https://ghcorps.org/zambia/, cited 10 ${ }^{\text {th }}$ April 2021; @ C UNC, 'Zambia' (online), available at: https://globalhealth.unc.edu/where-we-work/zambia/, cited $10^{\text {th }}$ April 2021.

55 (c) WHO, 'First Global Conference on Task Shifting', (online), available at: https://www.who.int/healthsystems/task_shifting/en/, cited $10^{\text {th }}$ April 2021

56 (c) WHO, 'Zambia’s COVID-19 home-based care relieves health facilities', (online), available at: https://www.afro.who.int/news/zambiascovid-19-home-based-care-relieves-health-facilities, updated $20^{\text {th }}$ August 2020, cited $3^{\text {rd }}$ February 2021. This approach may serve as an inspiration to other countries, although there is also a risk of spreading the infection in home setting, which calls for the need for supervision.

57 Zambia's performance in some of the core technical areas is relatively good, especially when compared with countries within the Southern 
Furthermore, the Ministry of Health implemented home management of Covid-19 infected patients to take the burden off the healthcare system and avoid severe overstretching of hospitals. ${ }^{58}$ Accordingly, under the home-based care system, asymptomatic and mildly symptomatic Covid-19 patients under fifty years of age without underlying conditions or co-morbidities have been cared for at home by families with the support of community-based volunteers. Only patients with moderate or severe symptoms are admitted to a health facility. The home-based care had been envisaged in the national response plan and became operational in May 2020. Rotating clinicians oversee the community volunteers. To ensure effective care at home, an environmental health officer assesses key aspects such as the number of people sharing a house, whether the patient can have a room to self-isolate and whether there is anyone with co-morbidities who could be at risk. Once the right conditions are met, a community health worker is assigned to provide care, making frequent visits to check progress and ensure that infection is not spread further in the community through those providing the home care. ${ }^{59}$

\section{(d) Traditional Medicine}

The limited access to the health care system left many to resort to traditional remedies. While the biomedical effectiveness of these remedies has not been always established, even if used as placebos, such medicines may contribute to a population's resilience to the adverse impact of the pandemic (medical, mental, economic, and social). Home-based care in Zambia includes the use of local-based solutions such as steaming and consuming vitamin-rich fruits, ginger, garlic, honey and cinnamon concoctions. ${ }^{60}$ Steaming hereby involves putting leaves of trees such as mangoes, guavas and eucalyptus into boiling hot water from which the steam rises. Reportedly the desire to resort to home-based solutions has taken a surge in Zambia. The Minister of Health Jonas Chanda echoed the President's remarks and said local home-based and traditional remedies were vital in managing less severe and non-symptomatic patients at home when he said, 'This is what we have always used before the western medicines came. The minister also emphasised that the home-based remedies should be used as supplements to the conventional methods provided by health experts.

Africa, including Zambia, has a long history of traditional medicine and practitioners, and its benefits are recognised. Both the international community and Zambia have long attempted to regulate the use of traditional medicine to prevent overreliance and/or its dangerous applications. Most recently, the Zambian Ministry of Health issued Guidelines for Research in Traditional, Complementary, and Alternative Medicine in Zambia in 2018. ${ }^{61}$ Facing the novel virus, the WHO

Africa region; for example, in antimicrobial resistance detection, surveillance of infections caused by antimicrobial-resistant pathogens, developing animal health workforce capacity, immunisation, laboratory testing for priority diseases, and risk communication. (C) WORLD BANK GROUP, 'Zambia Covid-19 emergence response and health systems preparedness project 2020, P174185', Washington: The World Bank, (online), available at: https://projects.worldbank.org/en/projects-operations/project-detail/P174185, updated $9^{\text {th }}$ February, cited $10^{\text {th }}$ April 2021.

58 (c) Otto BAKANO, 'Zambia's Covid-19 home-based care relives health facilities', World Health Organisation Zambia (online), available at: https://www.afro.who.int/news/zambias-covid-19-home-based-care-relieves-health-facilities, cited $13^{\text {th }}$ April 2021.

59 SADC reports that as of $20^{\text {th }}$ August 2020, about $75 \%-80 \%$ of confirmed cases in Zambia appear to be asymptomatic and of the 941 active cases $786(83.5 \%)$ were being cared for at home or in isolation centres. ( ) SOUTHERN AFRICAN DEVELOPMENT COMMUNITY, 'Regional response to covid - 19 pandemic', (online), available at: https://www.sadc.int/files/8616/0034/8253/COVID-19_12th_Report_ EN_mail.pdf, cited $10^{\text {th }}$ April 2021, p. 4.

60 ( ) XHINUANET, Home-based care solutions for Covid-19 prevention in Zambia on the rise (online), available at: http://www.xinhuanet. com/english/202101/20/c139684042.htm, cited $13^{\text {th }}$ April 2021.

61 (c) MINISTRY OF HEALTH, 'Guidelines for research in traditional, complementary, and alternative medicine in Zambia', (online), available at: https://static1.squarespace.com/static/5a76debf2aeba5bf135a4ea0/t/5be95e158a922d4a291fc1df/1542020638828/NHRA+ Guidelines+for+Research+in+TCAM-FINAL.pdf, cited $3^{\text {rd }}$ February 2021. 
and the Africa Centres for Disease Control and Prevention (Africa CDC) also established the Regional Expert Committee on Traditional Medicine for Covid-19 in July 2020 to formalise an independent scientific review and support countries on the safety, efficacy, and quality of traditional therapies. ${ }^{62}$ This was done to prevent the use of traditional practices and remedies that could be potentially harmful. However, anecdotally, the approval process did not stop Zambians from relying on traditional remedies, particularly in light of the lack of resources and access to health care. As mentioned above this may be beneficial if used as complementary and not as the alternative to standard evidence-based medicine. There are dangers linked to traditional medicine too: an extreme example is a Covid-19 denialism in Tanzania that misuses traditional medicine as an alleged panacea. This has made Tanzania a poorly performing country when it comes to Covid-19 response. ${ }^{63}$ Fortunately, Zambian public health officials did not adopt this eccentric approach.

A deep-seated belief in traditional remedies has been reflected also in the Zambian president's speeches in response to the Covid-19 pandemic. The President recommends home care solutions, such as 'steaming,' using eucalyptus leaves, ginger, garlic, honey, and cinnamon potions. ${ }^{64}$ The finding that all other control measures against the Covid-19 infection that Zambia's president outlines are lined with natural home care solutions strongly suggests the importance the Zambian president and population attach to these natural solutions. ${ }^{65}$ In addition to this, there are also various religious medical practices of faith-healing connected with African traditional medicine. ${ }^{66}$

\section{(e) Experience with Previous Epidemics}

Finally, in our overview of positive factors contributing to relative Zambia's success it is important to consider African perceptions of and experiences with past infectious diseases and how they have affected the Zambian response to the current pandemic. The factor of past experiences is generally recognised but sometimes it is not properly understood: the experiences with past infectious diseases as such would not be too helpful if not translated into a well-organised community-based approach to the protection of public health. This process starts with people's basic perception of the situation or a new epidemic phenomenon as risky even before it is locally manifested in actual sick or dying people. This perception is an important aspect for the effective control of infectious diseases in general. David S. Gochman (b. 1936), a U.S. professor of social work and an expert on health behaviour and health beliefs put together ample evidence from various empirical studies indicating a causal link between the cognitive factors and various behavioural results, such as compliance with public health recommendations. ${ }^{67}$ Gochman and many other authors working in this field argue that in what he defines as health behaviour, mental states such as beliefs, expectations, motives, values, perceptions, and other elements such as personality charac-

62 () WHO, 'Africa CDC push for COVID-19 traditional medicine research in Africa', (online), available at: https://www.who.int/news$\mathrm{room} /$ feature-stories/detail/who-africa-cdc-push-for-covid-19-traditional-medicine-research-in-africa, updated $22^{\text {nd }}$ July 2020 , cited $3^{\text {rd }}$ February 2021.

63 Cf. (C) Peter MWAI and Christopher GILES, 'Covid: Does Tanzania have a hidden epidemic?', BBC (online), available at: https://www. bbc.com/news/56242358, updated $7^{\text {th }}$ March 2021, cited $12^{\text {th }}$ April 2021.

64 Cf. () Mwape MWENYA, 'Ukufutikila: Getting back to basics, Zambia Daily Mail limited, Lusaka', (online) available at: http://www. daily-mail.co.zm/ukufutikila-getting-back-to-basics/, updated $4^{\text {th }}$ February 2021, cited $4^{\text {th }}$ February 2021.

65 Cf. () AIRHIHENBUWA, 'AIDS perspectives in Africa ..., pp. 57-69.

66 Cf. () Clive DILLON-MALONE, 'Mutumwa nchimi healers and wizardry beliefs in Zambia', Social Science \& Medicine, Volume 26, Issue 11, 1988 (online), available at: https://doi.org/10.1016/0277-9536(88)90191-8, cited $15^{\text {th }}$ January 2021, pp.1159-1172. Kaori SUGISHITA, 'Traditional Medicine, Biomedicine and Christianity in Modern Zambia'. Africa: Journal of the International African Institute, vol. 79, no. 3, 2009, pp. 435-454.

67 Cf. David S. GOCHMAN, ed., Guide to health behavior research I: personal and social determinants. New York: Plenary Press, 1997. 
teristics, affective and emotional traits, and overt behaviour patterns, actions, and habits, all relate to health maintenance, health restoration, and health improvement. ${ }^{68}$ Hence, public health must include a perception of both the risk and of the effectiveness of the recommended risk reduction measures or control. ${ }^{69}$ This has been shown even for particular diseases: perceptions drawn from people's mental representations largely shape the nature and extent of their behavioural responses to control health risks, such as SARS or H5N1. ${ }^{70}$

Covid-19 is not the first pandemic Africa has experienced. The continent has been through several other deadly pandemics and outbreaks of infectious diseases, such as Ebola, polio, HIV/ AIDS, resistant strains of Tuberculosis, malaria and other mosquito-borne diseases, yellow fever, typhoid, cholera, and many more. ${ }^{71}$ Zambia and SSA in general is also subject to other widely spread health problems, for example, cancer, including cancers related to a virus such as HPV and cervical cancer. Early detection, patient isolation and preventative measures developed in patient care during past epidemics can also be used to combat the currently new Covid-19. African countries have often well-established frameworks and systems of public and global health (Africa CDC, CDC Zambia), unlike some developed countries such as the Czech Republic and other countries of Central and Eastern Europe. This helps them to integrate and react in time to emergent infectious diseases with surprising and substantially greater effectiveness and success. In spite of various huge economic, social, and political problems, Africa is more effective when it comes to disease control than many countries in the West. The current pandemic is yet more evidence for it. Hence, Africa's history of infectious diseases and lessons taken from countries such as Zambia may be helpful and inspiring even for high-income countries in other continents and with other cultural traditions.

\section{Conclusions}

When it comes to mortality or the relative number of the infected, Covid-19 has so far had a much lesser negative impact on Zambia and many other SSA countries than WHO and many in the Western scientific community had predicted. ${ }^{72}$ While there may also be other reasons for this success, we focus here on the role of religiosity and spirituality, philosophy of life, global health approach, traditional medical remedies, and previous experiences with deadly epidemics and outbreaks. More research is needed in this area to explore the specific roles these factors play in increasing pandemic resilience. Furthermore, we are aware that we have not provided a complete general framework for pandemic resilience but have rather only drawn attention to some of the

68 Cf. Keith J. PETRIE and John WEIMANN, eds., Perception of health and disease. London: Harwood Academic, 1997, cf. especially the introductory chapters, pp. 19-46.

69 Cf. @ Jocelyn RAUDE and Michel SETBON, 'Lay perception of pandemic flu threat', European Journal of Epidemiology (online), available at: https://www.researchgate.net/publication/26255227_Lay_perceptions_of_the_pandemic_influenza_threat, cited 15 ${ }^{\text {th }}$ January 2021 , pp. 339-342.

70 Cf. ( ) Gabriel M. LEUNG et al., 'Health Impact of community psychological responses on control of outbreaks of severe acute respiratory syndromes in Hong Kong', J. Epidemiology and Community Health, 2003, 57(11) (online), available at: https://www.researchgate.net/ publication/9024514_The_impact_of_community_psychological_responses_on_outbreak_control_for_severe_acute_respiratory_ syndrome_in_Hong_Kong, cited $19^{\text {th }}$ January 2021, pp. 857-863; cf. @ Anja LEPPIN and Arja R. ARO, 'Perception of risks related to SARS and avian influenza: theoretical basis of current empirical research', International Journal of Behavioural Medicine (online), available at: https://pubmed.ncbi.nlm.nih.gov/19214752/, cited $3^{\text {rd }}$ January 2021, pp. 7-29.

71 Cf. @ Charlotte PAYNE, 'COVID-19 in Africa, Nature Human Behaviour', 2020/4 (online), available at: https://doi.org/10.1038/s41562020-0870-5, updated $3^{\text {rd }}$ April 2020, cited $2^{\text {nd }}$ January 2021, pp. 436-437.

72 Even from the economical point of view Africa appears to be more successful when dealing with the current pandemics, as economists such as Laundry Signé (cit. above) argue. 
factors we consider salient in Zambia. ${ }^{73}$

As 2020 was rather successful for Zambia, the country is looking with confidence and hope for further advances in 2021 with plans to begin vaccination against Covid-19 through allocation from the global initiative for equitable access to Covid-19 vaccines (COVAX) ${ }^{74}$ Despite the countless problems which low-income and medium-income African countries face, we hope to have shown in our paper that there are successes and relevant lessons to be learned from Zambia by other countries and regions too, including high-income ones.

\section{Contact \\ David Mutemwa}

The University of Barotseland

Research Unit

P. O. Box 910316 Mongu

Zambia

dmutemwa@hotmail.com

Auckland Park Theological Seminary

Department of Practical Theology

55 Richmond Avenue

Private Bag X75

Auckland Park, 2006, Johannesburg

South Africa

dmutemwa@hotmail.com

University of South Bohemia in České Budějovice

Faculty of Theology

Department of Social Work and Caritas Theory

Kněžská 8, 37001 České Budějovice

mutemd00@tf.jcu.cz

\section{Dr Veronika Zvánovcová}

University of South Bohemia in České Budějovice

Faculty of Theology

Department of Social and Charity Work

Kněžská 8, 37001 České Budějovice

zvanovcova@tf.jcu.cz

\section{Dr Anna Helová}

73 A case study of Singapore with a more general framework than ours is ( $)$ Wanfen YIP, et al, 'Building community resilience beyond COVID-19: The Singapore way., The Lancet Regional Health Western Pacific, 2021, Volume 7, (online), available at: https://www. thelancet.com/journals/lanwpc/article/PIIS2666-6065(20)30091-2/fulltext, cited 10 $0^{\text {th }}$ February 2021.

74 C ARCHDIOCESAN CHARITY PRAGUE, 'Zambia, What is the current situation in the countries where remote adoption helps?', (online), available at: https://praha.charita.cz/zahranici, updated $18^{\text {th }}$ January 2021, cited $23^{\text {rd }} J a n u a r y ~ 2021$. () WHO, 'Zambia launches the COVID-19 vaccination', (online), available at: https://www.afro.who.int/news/zambia-launches-covid-19-vaccination, cited $17^{\text {th }}$ April 2021. 
The University of Alabama at Birmingham

Sparkman Center for Global Health

UAB Sparkman Center for Global Health

517 RPHB 1665 University Blvd

Birmingham, Alabama 35205

United States

ahelova@uab.edu

\section{Dr Daniel D. Novotný}

University of South Bohemia in České Budějovice Faculty of Theology

Department of Philosophy and Religious Studies

Kněžská 8, 37001 České Budějovice

novotnyd@tf.jcu.cz 